\title{
The Use of Borrower-based Measures within Macroprudential Policy: Evidence from the European Economic Area
}

\author{
Lukáš Fiala - Petr Teplý
}

\begin{abstract}
:
The article deals with borrower-based instruments within macroprudential policy as measures aimed at reducing systemic risk regarding household debt. Our contribution is three-fold; Firstly, we show that more than $50 \%$ of countries in the European Economic Area have incorporated the borrower-based measures into their national legal framework. Secondly, we provide evidence that in countries exceeding the average level of household debt growth, more active caps are used. Thirdly, our results confirm the use of more than one active cap in countries where the house price increase was higher than average house price growth. We also highlight the reaction of the Czech National Bank and other authorities to the COVID-19 crisis, which has resulted in the relaxing of standards.
\end{abstract}

Key words: Household debt; Macroprudential policy; Borrower-based instrument. JEL classification: G51; G18.

\section{Introduction}

Following the 2007-2009 global financial crisis (GFC), financial stability became another important goal of central banks (Mishkin, 2011). The large economic costs of the crisis led to an attempt to trace the origins of the factors which had caused imbalances on the financial markets with negative effects on the real economy. In this context, household indebtedness and developments on the real estate markets were considered to be the sources of the crisis. In light of the serious negative impacts on economies, a large part of research activity started to examine the role of household debt and its links to the real estate market, with an effort to evaluate the implications for financial stability and the economic costs resulting from increasing household debt.

\footnotetext{
Lukáš Fiala; Prague University of Economics and Business, Faculty of Finance and Accounting, Department of Banking and Insurance, Winston Churchill Square 1938/4, 13067 Prague, Czech Republic, <fial01 @vse.cz>, ORCID ID: 0000-0002-6674-0955.

Petr Teplý; Prague University of Economics and Business, Faculty of Finance and Accounting, Department of Banking and Insurance, Winston Churchill Square 1938/4, 13067 Prague, Czech Republic, <petr.teply@vse.cz> , ORCID ID: 0000-0002-4014-918X.

This paper was supported by the Czech Science Foundation (Project No. GA 20-00178S), Prague University of Economics and Business (Project No. VSE IP100040 and No. IG102029).
} 
Fiala, L. - Teplý, P.: The Use of Borrower-based Measures within Macroprudential Policy: Evidence from the European Economic Area.

As a result of this research, the impacts on financial stability associated with household over-indebtedness and house price bubbles were evaluated as crucial. In order to reduce this type of risk, there was a national and supranational effort to focus on instruments and indicators which could help to protect the financial system against risk associated with household debt and real estate market development.

The first aim of this article is to provide an overview of the borrower-based instruments in force in the countries of the European Economic Area ${ }^{1}$ as of September 2020. These instruments are introduced successively according to the heterogeneity of their use with regard to the recommended limits and caps that are set on a legal basis. The second objective of this study is to explain the implementation of borrower-based instruments with regard to the development of household debt and house prices.

The remainder of the paper is structured as follows: In Section 2, we provide a literature review which explains the negative impacts of household (mortgage) debt and the role of macroprudential policy. In this section we also formulate three research hypotheses. In Section 3, we describe data and methodology. In this section we also present an overview of the borrower-based macroprudential measures used in the observed countries and demonstrate the heterogeneity in their implementation. We also indicate a set of variables that can explain the implementation of these instruments with a summary of results. In Section 4, we conclude the paper.

\section{Literature Review}

The GFC highlighted the need to focus on financial stability as another important goal, in addition to the inflation target that is generally accepted as the primary objective of central banks. In the light of the GFC's impacts on the global market, central banks and other supervisory institutions have started to concentrate on ensuring the stability of the financial system as an essential precondition for the functioning of the financial markets and economy.

With regard to the causes of the GFC, the increasing level of house prices, or their overvaluation, combined with a high level of household debt (especially resulting from loans secured by real estate) can be considered as the accumulating phase of risk for financial stability. The potential risks to financial stability resulting from mortgage markets depend highly on the development of this market

1 The European Economic Area consists of EU member states and three countries of the European Free Trade Association (Iceland, Liechtenstein and Norway, excluding Switzerland). The United Kingdom is also included because of its membership until the end of 2020. This area was formed by 31 countries as of 2020 . 
and, therefore, the risk is quite different in a cross-country perspective. Cerruti et al. (2017) analysed more than 50 countries in order to identify disparities between mortgage markets. The results of their country-by-country approach proved a positive statistical dependency between credit and homeownership and pointed out that measures promoting homeownership, such as the possibility to deduct mortgage interest payments from households' taxable income, or government agency loans or guarantees, are associated with the deepening of the mortgage market.

On the other hand, it is necessary to examine the role of household debt from the time perspective too, because of the different short-run and long-run effects on economic growth. The increasing level of household indebtedness can accelerate consumption and GDP growth in the short-run period, but tends to lower economic output in the long-run perspective. This is in line with the findings of Lombardi et al. (2017), who confirmed the positive impact of an increase in household debt-to-GDP ratio on consumption and GDP growth in the short-run. Otherwise, a higher level of this ratio causes lower consumption in the long-run, especially when this ratio exceeds $60 \%$.

The fluctuations in output associated with household debt can also be presented in the financial accelerator concept. Črič (2010) shows the role of the accelerator in the case of the GFC and suggests that financial markets can play an active role in short-run output changes. The role of the financial accelerator in the case of the subprime mortgage markets was also confirmed by Dell'Ariccia (2008). Gatti et al. (2010) claim that the financial accelerator can also be presented within a more complex view of credit relationships, which, through procyclical increases in borrowers' vulnerability at a time of economic boom, created the basis for financial crises and recession. This relationship can then lead to a series of bankruptcies.

Alter et al. (2018) present very similar findings regarding the consequences of household debt for the real economy. The evidence suggests that growth of one standard deviation leads to $1.2 \mathrm{pp}$ lower output in the next three years, with a stronger effect on advanced economies than on emerging markets. This study also presents a view on the likelihood of a banking crisis and the volatility of banks' stock returns. A higher level of household debt is considered to increase the probability of a banking crisis and, it should be emphasised, the negative effect is twice as large as in the case of the non-financial corporate debt.

Borio (2012) also confirms the important role played by credit when modelling the financial cycle for predicting and identifying financial imbalances and identifying the accumulation phase for risks. The classic feature of the financial cycle is best displayed by the connected behaviour of credit and property prices, and the top of the cycle is associated with systemic banking 
Fiala, L. - Teplý, P.: The Use of Borrower-based Measures within Macroprudential Policy: Evidence from the European Economic Area.

crises, which usually occur close to that top. Borio, Drehmann and Xia (2018) emphasize that the financial cycle can be a useful indicator for estimating recession risk. They provide variables that can be used as proxies for the financial cycle, such as debt service ratio. The evidence suggests that the use of the debt service ratio as a proxy has been proved to be an effective indicator for assessing recession risk over a three-year horizon. Drehmann et al. (2012) present the comovements of the cyclical components of the cycle. The variables with a cyclical nature which are used to construct the financial cycle are presented by correlation. This includes credit, credit-to-GDP and house prices, excluding equity prices, which are considered to behave differently according to residential property prices. Similar findings were also presented by Stremmel (2015), who shows the different approaches towards the construction of the financial cycle. The evidence suggests that the best-fitted financial cycle indicator is based on the credit-to-GDP ratio, credit growth (this includes credit for both the household sector and the nonfinancial sector) and the house-price-to-income ratio.

Feldstein (2007) describes the role of subprime mortgages at the beginning of the GFC. The role of subprime lending as one of the origins of the GFC was also confirmed by Mishkin (2011). Mian and Sufi (2019) also confirm that the credit supply conditions play a crucial role in speculative booms and busts in asset prices, which include house prices. Arslan et al. (2020) present the importance of the credit supply channel during the booms, because of the higher leverage opportunities of the banking sector. The evidence suggests that the deterioration of banks' balance sheets during a bust leads to the higher amplification of that bust. In this context, the authors point out the role of macroprudential policy, which should contribute to a more resilient financial sector.

However, it is necessary to divide subprime lending as presented by Feldstein (2007) into the categories of high-risk borrowers with very uncertain incomes, and low-income households. Low-income household borrowers are not risky as borrowers within subprime lending, whose higher sensitivity to shock was also shown by the IMF (2017), which emphasised the typical features of these groups, that is, a higher level of debt-to-income ratio and debt service-to-income ratio.

The OECD (2017) claims that during household credit booms, households may become more vulnerable not only to income- or interest rate shock. There is a very close relationship between household debt and real estate prices. In the phase of debt accumulation during a housing boom, there is a risk of the increasingly severe exposure of households to a serious fall in real estate prices. Cioccetta et al. (2016) present this transmission as follows: The growth of real estate prices increases the value of collateral, which improves the affordability of credit or investment. Banks are more willing to grant loans because of the fact 
that collateralized loans require lower risk weights than unsecured loans. When real estate prices start to fall, the value of collateral declines too, and this leads to a reduced borrowing capacity. This state has a negative impact on investment returns, which are lowered and do not cover debt services. The inability to meet debt payments results in an increase in credit default and non-performing loans, with negative consequences for the banking sector.

In the case of consumer mortgage, there are several factors affecting the risk of credit default. The ECB (2005) divides these factors into two parts - systematic and idiosyncratic. Systematic circumstances cover risks at a regional or national level, such as an increase in unemployment, changes in interest rates or real estate prices. Idiosyncratic risk is associated with an individual household, for example income loss due to injury, divorce or job loss. According to the ECB approach, financial risk consists of two areas - the financial resources effect and the financial commitment impact. The financial commitment effect is connected with changes in interest payment or family related expenses, whereas the financial resources impact is caused by reduced income flows or falling house prices.

In line with the risks mentioned above, the GFC demonstrated that real estate booms can cause a financial crisis with negative impacts on economic growth. Jorda et al. (2015) show credit-fuelled house price bubbles to be the drivers of several financial crises which are responsible for deeper recessions and slower recoveries. These findings are crucial when setting up policy measures within monetary policy and macroprudential policy.

The use of macroprudential policy tools is a result of research and a policy effort to reduce potential systemic risk in the financial system and maintain financial system resilience, which leads to greater financial stability and lowers the likelihood of adverse scenarios for the financial sector and real economy. The IMF (2013) also emphasises the complementary role of macroprudential policy with regard to microprudential policy toolkits.

In response to the GFC, the European Commission established the European Systemic Risk Board (ESRB) in 2010. ${ }^{2}$ The main aim of the ESRB (2018) is to conduct macroprudential oversight of the EU financial system and to contribute to systemic risk mitigation. In line with its mandate, the ESRB issues recommendations and warnings in order to mitigate systemic risk. Safeguarding financial stability and limiting the build-up of vulnerabilities as a primary goal of macroprudential policy has led the ESRB to identify four

2 The European Commission tasked the High Level group with examining how to improve and strengthen financial supervision in order to restore confidence in the financial system. The setting-up of the ESRB was based on the De Larosière report and Regulation (EU) No. 1092/2010 which entered into force in 2010. 
Fiala, L. - Teplý, P.: The Use of Borrower-based Measures within Macroprudential Policy: Evidence from the European Economic Area.

intermediate objectives ${ }^{3}$, one of which has been to deal with excessive credit growth and leverage as a key source of financial crises.

The ESRB $(2014,2018)$ introduces two different groups of tools when assessing and mitigating real estate risks. The first group covers instruments which target banks using higher capital requirements or higher risk weights applicable to exposures secured by mortgages on immoveable property. These measures are defined under CRR $\mathrm{II}^{4}$ or CRD $\mathrm{V}^{5}{ }^{6}$ The second group of instruments covers borrower-based lending limits that are not defined under the EU legislation.

The borrower-based instruments are aimed at restricting relatively the loan amount to the collateral value or borrowers' income. This includes the loan-to-value ratio (LTV), loan-to-income ratio (LTI) and debt service- to-income ratio (DSTI). The purpose of implementing the LTV is to lower the potential losses of the credit institution when a borrower defaults (lower $\mathrm{LGD}^{7}$ ). On the other hand, the LTI and DSTI caps affect the ability of the borrower to repay the debt and have a positive impact on the probability of default (PD). The advantage of this type of instruments is their direct form, in contrast to other macroprudential measures. The use of this set of measures improves the resilience of borrowers and at the same time that of banks. (ESRB 2018)

The research connected with the implementation of borrower-based instruments is mostly focussed on the impacts and effectiveness of their use (e.g. Jurča et al. (2020), Cassidy (2017), Lindner and Albacete (2017) or Gross and García (2016)). This research is based on an ex post assessment of the instruments' effects. On the other hand, some authors provide a set of variables that are presented as a basis for implementing instruments targeting borrowers. Bierut et al. (2015)

3 These aims were incorporated into the Recommendation of the ESRB of 4 April 2013 on intermediate objectives and instruments of macro-prudential policy (ESRB/2013/1).

4 CRR II is generally accepted label for Regulation (EU) 2019/876 of the European Parliament and of the Council of 20 May 2019 amending Regulation (EU) No 575/2013 as regards the leverage ratio, the net stable funding ratio, requirements for own funds and eligible liabilities, counterparty credit risk, market risk, exposures to central counterparties, exposures to collective investment undertakings, large exposures, reporting and disclosure requirements, and Regulation (EU) No 648/2012.

5 CRD V is a designation of Directive (EU) 2019/878 of the European Parliament and of the Council of 20 May 2019 amending Directive 2013/36/EU as regards exempted entities, financial holding companies, mixed financial holding companies, remuneration, supervisory measures and powers and capital conservation measures.

6 Competent authorities may set up higher risk weights for exposures secured by mortgages on residential property within the standard and IRB approach under the CRR. With regard to the implementation date of CRR II and CRD V, which has been set to the end of 2020, some authorities will set the measures in line with the previous regulation (CRR and CRD IV).

7 Loss given default can be defined as the amount that the credit institution suffers in the case of credit default. 
present the activation of limits in the case of Poland as a response to rapid credit growth and the loosening of lending standards. The CNB (2018) considered the tightening of the limits to be in line with the price overvaluation of residential real estate and the high level of newly issued mortgages. However, other factors used in ex ante analysis were not emphasized.

Based on the literature review, we present the following hypotheses examining the implementation at country level and from the perspective of macroeconomic variables:

Hypothesis 1: More than 50\% of the analysed countries incorporated the borrower-based measures objectives into their national legal framework as binding regulations.

Hypothesis 2: Countries with higher-than-average growth of household debt later introduced the use of more active caps.

Hypothesis 3: Countries with higher-than-average growth of house prices later introduced the use of more active caps.

\section{Research Design}

\subsection{Data and methodology}

In our paper, we use a comparative analysis as the primary toolkit, and correlation analysis as a supplementary one. The first part of the paper deals with mapping of the macroprudential borrower-based measures used in the 31 observed European economies, with an emphasis on the heterogeneity of the implementation of these instruments resulting from different legal systems, the number of limits used, and their changes over time. The second part focuses on the development of household debt and house prices as a supporting argument for implementing a borrower-based toolkit. The main characteristics of these variables are summarized in Table 1.

Tab. 1 Description of datasets

\begin{tabular}{lll}
\hline Variable & Frequency & Countries \\
\hline Lending for house & $2010-2019$ (annual & 28 countries: The EEA countries excluding \\
purchase & data) & Iceland, Liechtenstein and Norway \\
House price index & 2017Q3-2019Q4 & 29 countries: The EEA countries excluding \\
$(2015=100)$ & (quarterly data) & Greece and Liechtenstein \\
\hline
\end{tabular}

Source: ECB (2020), Eurostat (2020). 
Fiala, L. - Teplý, P.: The Use of Borrower-based Measures within Macroprudential Policy: Evidence from the European Economic Area.

\subsection{Empirical analysis}

The empirical analysis is divided into two parts. The first part shows the use of the macroprudential measures ${ }^{8}$ that are in force in European countries with the main aim to identify differences between the adjustments of the instruments used in each country. The second part is focussed on the factors that led national authorities to set up measures for reducing systemic risk resulting from the real estate sector.

As mentioned above, the ESRB (2013) only recommends the use of borrowerbased measures within macroprudential policy and their incorporation into the national legal framework. Anchoring rules for granting loans secured by mortgages ensures the legal obligation for targeted institutions and enforceability, which is important for meeting the objectives of each measure and protecting subjects from regulatory arbitrage in the case of non-bank mortgages providers.

In the examined sample of 31 economies, there are 23 countries which have incorporated into their national legal framework the possibility to set up one or more borrower-based instruments as a binding regulation. This also applies to the United Kingdom, where LTI is in force as a binding regulation under Art. 103 CRD. In the case of Austria, an LTV limit is not active as a macroprudential tool, but as a legal regulation. Despite the availability of a legal framework, the National Bank of Belgium has issued expectations on LTV limits, which are only recommended. The National Bank of Slovenia also recommends LTV limits, whereas a DSTI cap is in force under the law.

As Table 2 presents, there are twenty-two economies where the LTV ratio has been implemented, which represents more than half of the examined sample. Most of these countries set up LTV as a binding regulation, and only 5 of them recommend this limit. The LTI or DTI ratio has been active in 7 out of 31 observed economies, and the LSTI or DSTI ratio has been in force in 14 countries. With regard to the form of implementation, a larger number of income caps have been in force under the law as a binding regulation. Apart from that, 7 countries have not had any active limit. Germany, Spain and Luxembourg can set up caps under their national legal framework, while in Luxembourg other measures are used. Table 2 also shows that 11 economies have set up limits on time

8 In empirical analysis, the terms "borrower-based measures", "instruments" and "tools" are considered to have the same meaning. As the active cap, we consider only those limits that cannot be exceeded or are recommended not to be exceeded. 
to maturity (including both binding regulations and recommendations), which means one third of the sample.

Tab. 2 The total number of countries which have implemented the instruments targeting borrowers

\begin{tabular}{|c|c|c|}
\hline Form & Measure & Countries where the limits were in force as of September 2020 \\
\hline \multirow{3}{*}{$\begin{array}{l}\text { Recommended } \\
\text { limits }\end{array}$} & LTV & 5 countries: BE, CZ, MT, PL, SI \\
\hline & LTI/DTI & 2 countries: BE, DK \\
\hline & LSTI/DSTI & 5 countries: AT, BE, MT, PL, PT \\
\hline \multirow{3}{*}{ Binding limits } & LTV & $\begin{array}{l}17 \text { countries: AT, CY, DK, EE, FI, HU, IS, IE, LV, LI, LT, } \\
\text { NL, NO, PT, RO, SE, SK }\end{array}$ \\
\hline & LTI/DTI & 5 countries: $\mathrm{IE}, \mathrm{LV}, \mathrm{NO}, \mathrm{SK}, \mathrm{UK}$ \\
\hline & LSTI/DSTI & 9 countries: CY, EE, FR, HU, LV, LT, RO, SK, SI \\
\hline Any active limit & & 7 countries: BG, DE, ES, GR, HR, IT and LU \\
\hline Maturity & & 11 countries: AT, CZ, EE, FR, LI, LT, LV, MT, PL, PT, SK \\
\hline Legal framework & & $\begin{array}{l}23 \text { countries: AT, BE, CY, DE, EE, ES, FI, HU, IE, IS, LI, } \\
\text { LU, LT, LV, MT, NL,NO, PT, RO, SE, SI, SK UK }\end{array}$ \\
\hline Other regulation & & $\begin{array}{l}20 \text { countries: AT, BE, CY, CZ, DK, EE, FI, HU, IE, LI, LT, } \\
\text { LU, MT, NO, PL, PT, RO, SI, SK, UK }\end{array}$ \\
\hline ESRB warning & & $\begin{array}{l}\text { November 2016: AT, BE, DK, FI, LU, NL, SE, UK } \\
\text { September 2019: CZ, DE, FR, IE, NO }\end{array}$ \\
\hline
\end{tabular}

Source: ESRB (2020), national legislation.

Note: Maturity limits cover both binding limits and recommended limits. Other regulation covers other measures that are used as additional instruments to the macroprudential ratios, for example, stress testing, limitations on granting loans for other real estate, other measures under CRD or CRR, different caps for foreign currency loans, exceptions from standard limits etc.

As mentioned above, only seven countries have implemented the LTI or DTI ratio. On the other hand, there are nine economies which have set up an LSTI or DSTI cap and maturity limit together (AT, EE, FR, LV, LT, MT, PL, PT and SK). This combination, in fact, means a limitation of the loan amount in relation to the applicants' income, i.e. it has the same impact as implementing the LTI or DTI ratio.

There are also instruments that are usually used as an additional regulation when implementing macroprudential ratios. These instruments cover exceptions from the standard limits, i.e. when the thresholds of each cap are exceeded. These exceptions are mostly defined as a certain percentage of loan provision in a certain time period (quarterly or annually). Other measures also include 
Fiala, L. - Teplý, P.: The Use of Borrower-based Measures within Macroprudential Policy: Evidence from the European Economic Area.

the different caps used when purchasing more real estate, or when drawing the loan in a foreign currency (for example in the cases of Romania or Hungary). Stress tests for assessing the ability to repay the loan in the case of an interest rate rise are classified within that set of instruments too, as well as measures resulting from CRD or CRR (higher risk weights for mortgage-secured loans). Some instruments from this set of measures are in force in twenty countries.

The number of borrower-based instruments used within macroprudential policy could be the result of ESRB activity when assessing national risks and warnings issued. ${ }^{9}$ As Table 2 presents, the ESRB has issued thirteen warnings since 2016. The ESRB has highlighted increasing household indebtedness in relation to household income, which could lead to medium-term vulnerability on the residential real estate market according to the issued warnings. The ESRB also pointed out the potential risk resulting from house price growth and the potential overvaluation of houses in some countries.

Table 3 shows that the active caps in most of the observed economies have not been changed since their activation. There are only a few countries, where these limits have been changed more often, such as the Czech Republic. Table 3 provides evidence that the Czech National Bank has revised the level of active limits (especially LTV and DSTI ratio) on an annual basis. As a response to the coronavirus crisis, the CNB abolished the DSTI and DTI limits, while the LTV cap has been increased by $10 \%$. Another example is the Netherlands, where the LTV limits were changed six years in a row. These adjustments were, however, known in 2012 when the first limit came into force. In the rest of the observed countries, the active limits were not changed often. As a response to the coronavirus crisis, Norges Bank relaxed the amount of approved loans exceeding the threshold of each cap. The Banco de Portugal also adopted some changes in loan assessment due to the crisis. In this case, loans with maturity of up to two years were exempted from the DSTI limit until September 2020.

Tab. 3 Active limits with dates of coming into force

\begin{tabular}{llll}
\hline Country & LTV limits & LSTI/DSTI limits & LTI/DTI limits \\
\hline Austria (AT) & $\mathbf{8 0 \%}(9 / 2018)$ & $\mathbf{4 0 \%}(9 / 2018)$ & - \\
Belgium (BE) & $\mathbf{9 0 \%}(1 / 2020)$ & $\mathbf{5 0 \%}(1 / 2020)$ & $\mathbf{9}(1 / 2020)$ \\
Cyprus $(\mathrm{CY})$ & $\mathbf{8 0 \%}(12 / 2013)$ & $\mathbf{6 0 \%}(12 / 2013) ; \mathbf{8 0 \%}$ & -
\end{tabular}

9 Warnings on medium-term vulnerabilities in the residential real estate sector are available at: https://www.esrb.europa.eu/mppa/warnings/html/index.en.html. 


\begin{tabular}{|c|c|c|c|}
\hline Country & LTV limits & LSTI/DSTI limits & LTI/DTI limits \\
\hline Czech Republic (CZ) & $\begin{array}{l}\mathbf{1 0 0 \%}(6 / 2015) ; \mathbf{9 5 \%} \\
(9 / 2016) ; \mathbf{9 0 \%}(4 / 2017) ; \mathbf{8 0 \%} \\
(6 / 2018) ; \mathbf{9 0 \%}(4 / 2020)\end{array}$ & $\begin{array}{l}\mathbf{4 0 \%}(6 / 2017) ; \mathbf{4 5 \%} \\
(6 / 2018) ; \mathbf{5 0 \%}(4 / 2020) ; \text { no } \\
\text { active limit }(6 / 2020)\end{array}$ & $\begin{array}{l}8(6 / 2017) ; 9 \\
(6 / 2018) ; \text { no } \\
\text { active limit } \\
(4 / 2020)\end{array}$ \\
\hline Denmark (DK) & $\begin{array}{l}\mathbf{9 5 \%}(11 / 2015) ; \mathbf{8 0 \%} \\
(3 / 2017)\end{array}$ & - & $4(2 / 2016)$ \\
\hline Estonia (EE) & $\mathbf{8 5 \%}(3 / 2015)$ & $\mathbf{5 0 \%}(3 / 2015)$ & - \\
\hline Finland (FI) & $\mathbf{9 0 \%}(7 / 2016) ; \mathbf{8 5 \%}(7 / 2018)$ & - & - \\
\hline France (FR) & - & 33\% $(1 / 2020)$ & - \\
\hline Hungary (HU) & $\mathbf{8 0 \%}(1 / 2015)$ & $60 \%(1 / 2015)$ & - \\
\hline Ireland (IE) & $\mathbf{8 0 \%}(2 / 2015)$ & - & $3.5(2 / 2015)$ \\
\hline Iceland (IS) & $85 \%(7 / 2017)$ & - & - \\
\hline Liechtenstein (LI) & $\mathbf{8 0 \%}(2 / 2015)$ & - & - \\
\hline Lithuania (LT) & $\mathbf{8 5 \%}(11 / 2011)$ & $\begin{array}{l}\mathbf{4 0 \%}(11 / 2011) ; \mathbf{6 0 \%} \\
(11 / 2015)\end{array}$ & - \\
\hline Latvia (LV) & $\mathbf{9 0 \%}(7 / 2007)$ & $40 \%(6 / 2020)$ & $6(6 / 2020)$ \\
\hline Malta (MT) & $\mathbf{9 0 \%}(7 / 2019)$ & $40 \%(7 / 2019)$ & - \\
\hline Netherlands (NL) & $\begin{array}{l}\mathbf{1 0 6 \%}(1 / 2012) ; \mathbf{1 0 5 \%} \\
(1 / 2013) ; \mathbf{1 0 4 \%}(1 / 2014) ; \\
\mathbf{1 0 3 \%}(1 / 2015) ; \mathbf{1 0 2 \%} \\
(1 / 2016) ; \mathbf{1 0 1 \%}(1 / 2017) \\
\mathbf{1 0 0 \%}(1 / 2018)\end{array}$ & - & - \\
\hline Norway (NO) & $\mathbf{9 0 \%}(3 / 2010) ; \mathbf{8 5 \%}(1 / 2011)$ & - & $5(1 / 2017)$ \\
\hline Poland (PL) & $\begin{array}{l}\mathbf{9 5 \%}(1 / 2014) ; \mathbf{9 0 \%}(1 / 2015) \\
\mathbf{8 5 \%}(1 / 2016) ; \mathbf{8 0 \%}(1 / 2017)\end{array}$ & $\mathbf{5 0 \%}(1 / 2014)$ & - \\
\hline Portugal (PT) & $\mathbf{9 0 \%}(7 / 2018)$ & $\mathbf{5 0 \%}(7 / 2018)$ & - \\
\hline Romania (RO) & $\mathbf{8 5 \%}(10 / 2011)$ & $\mathbf{4 0 \%}(1 / 2019)$ & - \\
\hline Sweden (SE) & $\mathbf{8 5 \%}(10 / 2010)$ & - & - \\
\hline Slovenia (SI) & $\mathbf{8 0 \%}(9 / 2016)$ & $\mathbf{5 0 \%}(9 / 2016)$ & - \\
\hline Slovakia (SK) & $\begin{array}{l}\mathbf{1 0 0 \%}(1 / 2014) ; \mathbf{9 0 \%} \\
(7 / 2018)\end{array}$ & $\begin{array}{l}\mathbf{8 0 \%}(3 / 2017) ; \mathbf{6 0 \%} \\
(1 / 2020)\end{array}$ & $8(7 / 2018)$ \\
\hline $\begin{array}{l}\text { United Kingdom } \\
\text { (UK) }\end{array}$ & - & - & 4,5 (10/2014) \\
\hline
\end{tabular}

Source: ESRB (2020).

As mentioned in the literature review, developments on the mortgage market play a crucial role when implementing macroprudential borrower-based instruments. Figure 1 shows the changes in household debt resulting from house purchases 
Fiala, L. - Teplý, P.: The Use of Borrower-based Measures within Macroprudential Policy: Evidence from the European Economic Area.

for 2010-2019 in comparison to the average change for same time horizon. As the figure illustrates, there are some economies where these changes reached a very high level. Examples of this include Belgium, Malta, Romania and Slovakia, where the total outstanding change exceeded the threshold of $100 \%$. The case of Slovakia represents the highest level of market increase and tends to $200 \%$. This development was reflected by the incorporation of borrower-based instruments into the national legal framework, which came into force in 2017.

Despite significant debt growth, Belgium adopted the recommendation of limits in 2020, and in Malta the recommended limits have been active since July 2019. In the case of Romania, some instruments are active as binding regulations, and the DSTI limit came into force there in January 2019. Significant growth has been observed in the Czech Republic, where, over nine years, there was an increase of nearly $80 \%$, or in Luxembourg, where the debt increase surpassed 90\%. The Czech National Bank has recommended certain limits as a response to rapid credit growth. With regard to the coronavirus crisis, the DSTI and DTI limits have been abolished and LTV relaxed since June 2020. On the other hand, there were countries where total debt declined, even though borrower-based instruments were active there. This applies, for example, to Cyprus, Hungary or Ireland, which experienced a drop in debt of $28.1 \%, 30.1 \%$ and $23.2 \%$, respectively.

Fig. 1 Percentage changes in total household debt outstanding resulting from housing purchases between 2010 and 2019

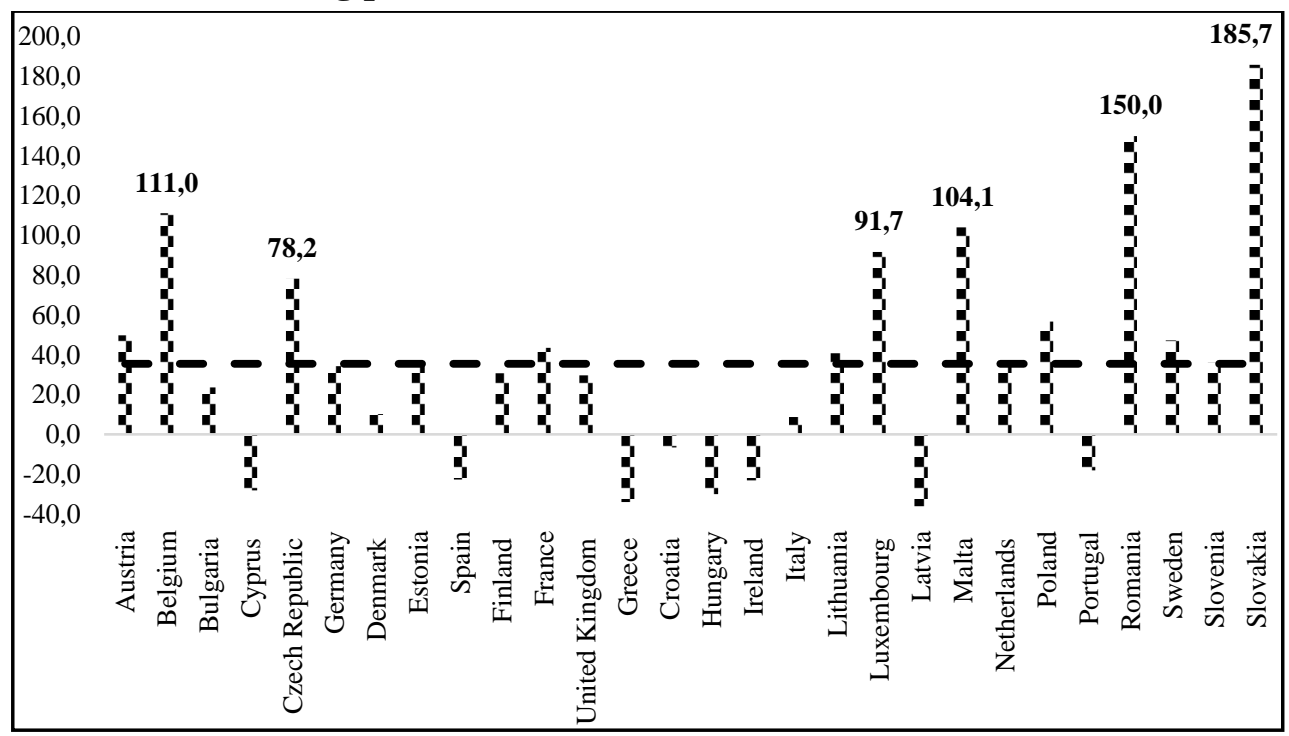

Source: ECB (2020). 
Note: The changes are based on lending for housing purchases to households and nonprofit institutions serving households (S.14 and S.15) at the end of the period in EUR. The dashed line shows the average 2010-2019 change across the observed countries.

Despite certain heterogeneity in the implementation of borrower-based instruments in the observed countries, the development of household debt can be considered to be one of the important factors influencing that implementation. This was confirmed in countries where the change in household debt exceeded the average change in the observed economies. In those countries, more than one cap has been activated: for example in Belgium or Slovakia (three caps) or Austria, Estonia, Malta, Poland, Romania or Slovenia (two limits). This result is also particularly confirmed by correlation analysis, which shows a positive relationship between the number of active instruments and changes in household debt resulting from housing purchases (correlation analysis results are provided in Table A.1 in the Appendix). However, there are also economies - such as Portugal, Latvia, Hungary or Cyprus - which have more than one active cap despite a decline in household debt.

Figure 2 illustrates house prices development between 2015 and 2019 based on the house price index. The dashed line displays the average change in house prices in the countries tested, where house prices gained by $35 \%$. The highest growth was observed in Hungary, where house prices increased by almost $72 \%$ between 2015 and 2019. On the other hand, Hungary did not receive an ESRB warning and the total debt had a declining tendency. Otherwise, Hungary implemented a set of measures targeting borrowers which covered the LTV and DSTI ratios with an emphasis on granting secured loans in different currencies. There are also other economies where house price growth exceeded the EU average (such as IS, SK or RO), but the ESRB did not warn them. However, all of these countries have implemented the LTV ratio. The house price changes ranged from $32.7 \%$ (DE) to $51.66 \%$ (IE) during the observed time period in the economies which were warned by the ESRB.

In its warning, the ESRB highlighted that a high level of house prices can contribute to increasing risks for financial stability associated with the real estate market. In this context, there is a potential risk resulting from price overvaluation, which can play a negative role in price correction, with an impact on banks' balance sheets. From the national perspective, the CNB (2020) considered house prices overvalued by approximately $20 \%$ in June 2020 .

The ECB (2020) shows that there are countries (AT, DE and LU) where house prices tend to be more overvalued and households are more likely to take out higher loans in relation to their income. The outputs of the ECB's research also confirmed a reduction in the average mortgage loan interest rate by $0.2 \mathrm{pp}$ 
Fiala, L. - Teplý, P.: The Use of Borrower-based Measures within Macroprudential Policy: Evidence from the European Economic Area.

between 2016 and 2018, a lengthening of maturities and an increase in the average LTV, LSTI and LTI. The analysis outcomes based on micro data covering the EA new business volume of residential real estate loans showed that the average LTV ratio reached $81 \%$ (80\% in 2016), average LTI was 4.4 (4.0 in 2016) and average LSTI 24.4 (24.0\% in 2016), which can be considered a supporting argument for activating the limits of borrower-based instruments.

As Table 2 and Table 3 show, the most widely used instrument is LTV, which is active in 17 countries as a binding regulation and in 5 economies as a recommended limit. Although Table 3 confirms that the LTV caps in many countries have not been changed since their activation, the widespread use of this instrument corresponds to the house price development in most countries. In this context, we consider house price development as a crucial indicator when implementing borrower-based measures. This conclusion is also highlighted by more active limits in countries where house prices grew faster than the average change in the given economy. Most of these economies have activated more than one cap; for example, Estonia, Lithuania, Hungary, Malta, Austria, Portugal and Slovenia (two active limits). In some countries exceeding the average growth, three caps have been active; for example, Slovakia or Latvia (also the Czech Republic until the limits were abolished). This finding may also be supported by correlation analysis results that show a positive relationship between the number of active instruments and changes in house prices because of the positive correlation coefficient (see Table A.1 in Appendix). 


\section{Fig. 2 House prices growth between 2015 and 2019 in percentage points}

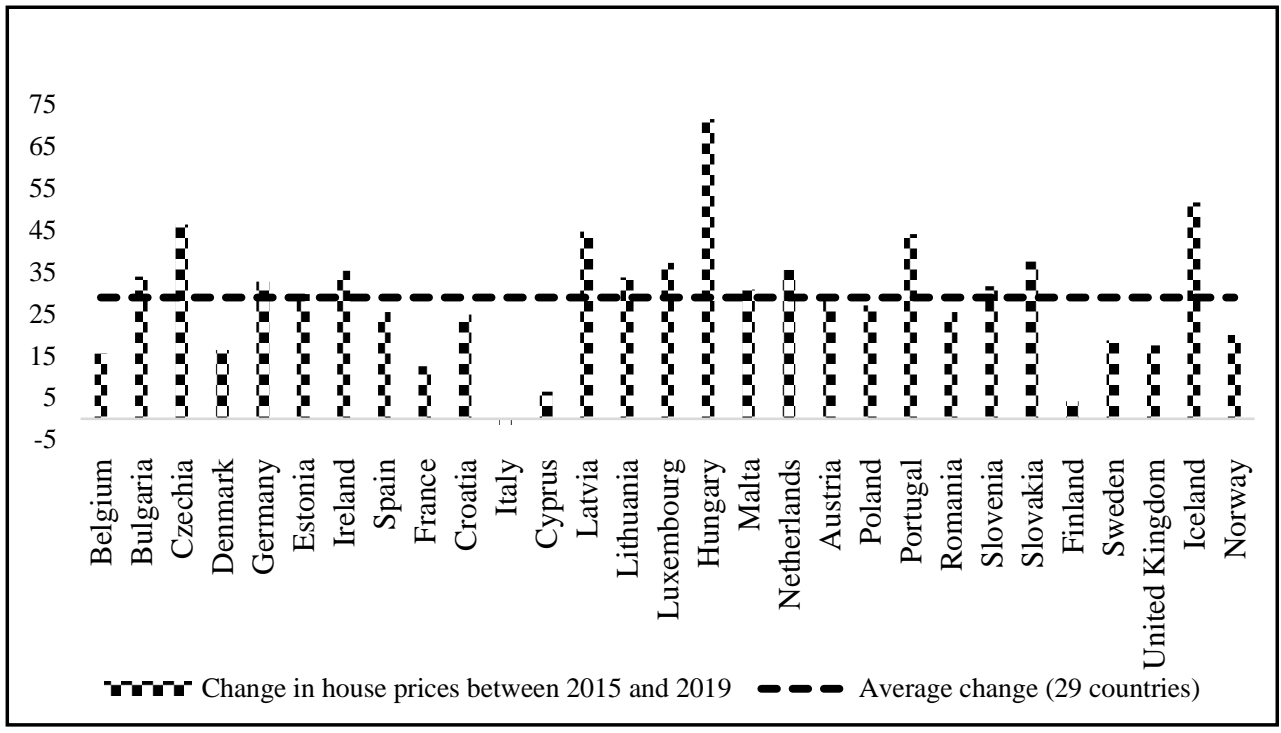

Source: Eurostat (2020).

Note: The changes are based on House price index data $(2015=100)$ which measure the price changes of all residential properties purchased by households. The dashed line shows the average 2015-2019 change across the observed economies.

\section{Results and Discussion}

\section{Hypothesis 1}

Firstly, we identify the relatively widespread use of instruments targeting borrowers. 22 economies out of the 31 observed have an active LTV ratio. This result includes 17 countries where this limit has been active as a binding regulation and 5 economies where the cap is recommended. Either LTI or DTI is in force in 7 countries, whereas LSTI or DSTI is implemented in 14 countries. Our findings suggest that a larger number of countries have implemented these instruments as a binding regulation -5 countries in the case of LTI/DTI and 9 countries in the case of LSTI/DSTI. Our analysis also shows that there are 23 economies with a legal framework which allows the implementation of caps under national legislation as a binding regulation. Moreover, we highlight 11 countries which use limits on loan maturity as an additional measure to complement macroprudential ratios and we add further statistics on 20 economies using other measures. These results are in line with the first hypothesis and also in line with the ESRB (2020) and IMF (2018). 
Fiala, L. - Teplý, P.: The Use of Borrower-based Measures within Macroprudential Policy: Evidence from the European Economic Area.

\section{Hypothesis 2}

Secondly, we analyse the growth of outstanding household debt between 2010 and 2019 in selected countries. The results show a significant increase in household debt resulting from house purchases, which is more noticeable in those countries which exceed the average growth of all the tested economies. Most of these economies have implemented more than one borrower-based instrument, such as Belgium and Slovakia (three caps) or Austria, Estonia, Malta, Poland, Romania and Slovenia (two limits). By contrast, there are some countries where the household debt had a declining tendency, but more than one cap was activated (for example Portugal, Latvia, Hungary or Cyprus). As supplementary evidence, we provide a correlation analysis that shows a positive relationship between active caps and changes in household debt associated with the purchase of housing.

\section{Hypothesis 3}

Our analysis also presents a view on house price development between 2015 and 2019 and suggests that there has been robust growth exceeding the average change in the tested sample. Most of these economies have activated more than one cap; for example, Estonia, Lithuania, Hungary, Malta, Austria, Portugal or Slovenia (two active limits). In some countries exceeding the average growth, three caps have been active; for example in Slovakia or Latvia (also in the Czech Republic until the limits were abolished). As supplementary evidence, we provide a correlation analysis that shows a positive relationship between active caps and changes in household debt associated with the purchase of housing, and changes in house prices.

In comparison to other research conclusions, the OECD (2017) claims that, due to the experience of the GFC, there are different approaches to implementing regulation. Firstly, there are countries where there is an effort to restart their investment in housing (for example DE, NL, SI) and where there is a macroprudential tool in place because of the increased demand for owner occupation. In these countries, there were only a few problems during the GFC. Secondly, there are economies with little lending, where the mortgage markets have not recovered (such as GR, HU, ES or PT). Thirdly, there are countries which strengthened their regulatory framework, but where there are no significant constraints on demand, and fourthly, there is a very small number of countries where regulatory constraints are used (UK).

\section{Further research opportunities}

Despite the conclusions presented above, there are still several ways in which our research can be improved. Firstly, a similar study could be carried 
out for some of the countries with more detailed data and better methodology (for example panel analysis). Secondly, the data used in the analysis could also be of a cyclical nature, such as newly issued loans or the development of credit standards, which provide more useful information for setting up the observed measures. Finally, further analysis could also be focussed on the changes in active borrower-based measures introduced as a response to the recent COVID-19 crisis.

\section{Conclusions}

The paper focuses on the use of borrower-based instruments within macroprudential policy. Our contribution is three-fold. Firstly, we examine the use of instruments targeting borrowers in 31 countries in the European Economic Area. We highlight measures with an emphasis on the form of their implementation. Secondly, we present the implementation of these instruments in the context of household debt development. Thirdly, we show the use of the measures in line with house prices changes.

We tested 3 hypotheses and came to three conclusions. Firstly, we suppose a relatively widespread incorporation of borrower-based measures into the national legal framework. Results of the study confirm that more than $50 \%$ of the observed economies incorporated these objectives into their national legal framework ( 23 economies out of 31 observed). Of the various instruments, the most widely used measure is LTV (22 economies). LTI or DTI are implemented in 7 economies, and LSTI or DSTI are active in 14 countries. As an additional regulation, limits on loan maturity have been set up in 11 countries, while other forms of regulation are in force in 20 economies. Our analysis also provides evidence that some countries (the Czech Republic, Norway and Portugal) relaxed the rules as a response to the coronavirus crisis. These changes were more noticeable in the Czech Republic, where the debt-to-income and debt service-to-income ratios were abolished.

Secondly, we expected that countries with higher-than-average household debt growth had implemented more than one instrument. Our findings suggest that most of these economies have implemented more than one borrower-based instrument, including Belgium or Slovakia (three caps), or Austria, Estonia, Malta, Poland, Romania or Slovenia (two limits). This finding was also supported by correlation analysis.

Thirdly, we assume that a higher-than-average house prices increase causes the activation of more than one cap. Our results show that most of the observed economies have activated more than one cap; for example, Estonia, Lithuania, Hungary, Malta, Austria, Portugal or Slovenia (two active limits). In some countries exceeding average growth, three caps have been active - such 
Fiala, L. - Teplý, P.: The Use of Borrower-based Measures within Macroprudential Policy:

Evidence from the European Economic Area.

as Slovakia or Latvia (also the Czech Republic until the abolition of the limits). This conclusion was also supported by correlation analysis.

\section{References}

Cerruti, E., DAGHER, J., Dellacariccia, G., Blanchard, O., 2017. Housing finance and real-estate booms: A cross-country perspective. Journal of Housing Economics 38. DOI: 10.1016/j.jhe.2017.02.001.

Ciocchetta, F., Cornacchia, W., Felici, R., Loberto, M., (2016): Assessing financial stability risks arising from the real estate market in Italy. ISSN 19726643.

Gatti, D. D., Gallegati, M., Greenwald, B., Russo, A., Stiglitz, J. E., 2010. The financial accelerator in an evolving credit network. Journal of Economic Dynamics and Control. DOI: 10.1016/j.jedc.2010.06.019.

Mishkin, F. S., 2011: Over the Cliff: From the Subprime to the Global Financial Crisis. Journal of Economic Perspectives, Vol. 25, No. 1, Available from: <https://ssrn.com/abstract=1949310>.

Alter, A., Xiaochen F., A., Valckx, N., 2018. Understanding the Macro-Financial Effects of Household Debt: A Global Perspective. IMF working paper, Vol. 18 (No.76).

Arslan, Y., Guler, B., Kuruscu, B., 2020. Credit supply driven boom-bust cycles. BIS working papers. No. 885, Available from: <bis.org/publ/work885.htm〉.

BORIO, C., 2012. The financial cycle and macroeconomics: What have we learnt? BIS working papers, (No. 395), Vol. 38. ISSN: 1682-7678.

Bierut, B., Chemielewski, T., Glogowski, A., Stopczynski, A., Zajaczkowski, S., 2015. Implementing loan-to-value and debt-to-income ratios: Learning from country experiences. The case of Poland. NBP working papers, No. 212.

Borio, C., Drehmann, M., Xia, D., 2018. The financial cycle and recession risk. BIS Quarterly review - December 2018. Available from: SSRN: <ssrn.com/abstract $=3316364$ >

Cassidy, M., 2017. Impact assessment of borrower-based (LTV/LTI) measures in Ireland. Central bank of Ireland. Macroprudential policy conference 2017 (11-12 May 2017).

Črič, B., 2011. The financial accelerator effect: concept and challenges. Financial theory and practice, (No. 2), Vol. 35, Available from: <hrcak.srce.hr/71539>. 
Dell'ariccia, G., Igan, D., Laeven, L., 2012. Credit booms and lending standards: Evidence from the subprime mortgage market. IMF working papers, DOI: 10.1111/j.1538-4616.2011.00491.x.

Drehmann, M., Borio, C., Tsatsaronis, K., 2012. Characterising the financial cycle: don't lose sight of the medium term! BIS Working papers, No. 380.

Feldstein, M. S., 2007. Housing, credit markets and the business cycle. National bureau of economic research Working paper No. 13471.

Gross, M., Garcia, F. J. P., 2016. Assessing the efficacy of borrower-based macroprudential policy using an integrated micro-macro model for European households. ECB working papers, No. 1881.

Jorda, Ò., Schularick, M., Taylor, A. M., 2015. Leveraged Bubbles. National bureau of economic research No. 21486. DOI: 10.3386/w21486.

Jurča, P., Klacso, J., Tereanu, E., Forletta, M., Gross, M., 2020. The effectiveness of borrower-based macroprudential measures: a quantitative analysis for Slovakia. IMF working papers, No. 134.

Lindner, P., Albacete, N., 2017. Simulating impacts of borrower based macroprudential policies on mortgages and the real estate sector in Austria evidence from the Household Finance and Consumption Survey 2014. Central bank of Austria. Workshop on "Data needs and Statistics compilation for macroprudential analysis" on 18-19 May 2017.

Mian, A., Sufi, A., 2019. Credit supply and housing speculation. National bureau of economic research No. 24823. DOI: 10.3386/w24823.

Lombardi, M., Mohanty, M., Shim, I., 2017. The real effects of household debt in the short and long run. BIS Working Papers No. 607. ISSN 1682-7678.

Stremmel, H., 2015. Capturing the financial cycle in Europe. ECB Working paper series No. 1811. Available from: 〈ssrn.com/abstract=2621651〉.

Czech National Bank, 2020. Financial stability report 2019/2020. ISBN 978-8087225-95-0, Available from: <cnb.cz/cs/financni-stabilita/zpravy-fs/zprava-ofinancni-stabilite-2019-2020/>.

Czech National Bank, 2018. Financial stability report 2017/2018. ISBN 978-8087225-79-0, Available from: <cnb.cz/cs/financni-stabilita/zpravy-fs/zprava-ofinancni-stabilite-2017-2018/>.

European Central Bank, 2005. Financial stability review - December 2005. ISSN 1830-2025. Available from: <ecb.europa.eu/pub/pdf/fsr/financialstab ilityreview200512en.pdf>. 
Fiala, L. - Teplý, P.: The Use of Borrower-based Measures within Macroprudential Policy: Evidence from the European Economic Area.

European Central Bank, 2020. Financial Stability Review - May 2020. ISBN 1830-2025. Available from: <ecb.europa.eu/pub/financial-stability/fsr/ht ml/index.en.html>.

European Systemic Risk Board, 2020. A Review of Macroprudential Policy in the $\mathrm{EU}$ in 2019. ISBN 978-92-9472-141-9, Available from: <esrb.euro pa.eu/pub/reports/re view_macroprudential_policy/html/index.en.html>.

European Systemic Risk Board, 2014. Flagship Report on Macro-prudential Policy in the Banking Sector. Available from: <esrb.europa.eu/pub/pdf/othe r/140303_flagship_report.pdf>.

European Systemic Risk Board, 2018. The ESRB handbook on operationalising macroprudential policy in the banking sector. ISBN 978-92-9472-028-3. Doi: $10.2849 / 04791$.

International Monetary Fund, 2017. Global Financial Stability Report October 2017: Is Growth at Risk? ISBN 978-1-48432-059-4, Available from: <imf.org/en/Publications/GFSR/Issues/2017/09/27/global-financial-stabilityreport-october-2017>.

International Monetary Fund, 2013. Key aspects of macroprudential policy. Available from: <imf.org/en/Publications/Policy-Papers/Issues/2016/12/31/KeyAspects-of-Macropr udential-Policy-PP4803>.

International Monetary Fund, 2018. Regional economic outlook: Europe: Domestic Expansion Running into External Turbulence. November 2018. ISBN 9781484375402, Available from: <elibrary.imf.org/view/IMF086/254169781484375402/25416-978148437 5402/ch02.xml?language=en\&redirect=true >

Organisation for Economic Co-operation and Development (OECD), 2017. Changes in the regulation and control of mortgage markets and access to owneroccupation among younger households. (No. 196). ISSN 1815199X. Doi: $10.1787 / 1815199 X$.

Organisation for Economic Co-operation and Development (OECD) 2017. OECD Economic outlook - resilience in a time of high debt. Available from: $<10.1787 /$ eco_outlook-v2017-2-en>.

Recommendation of the ESRB of 4 April 2013 on intermediate objectives and instruments of macro-prudential policy (ESRB/2013/1). Available from: <esrb.europa.eu/mppa/rec ommendations/html/index.en.html>. 


\section{Appendix}

Table A1 - correlation analysis results

\begin{tabular}{|c|c|c|}
\hline Variable & $\begin{array}{c}\text { Correlation } \\
\text { coefficient } \\
\text { (t-stats; } p \text {-value) }\end{array}$ & Countries \\
\hline $\begin{array}{l}\text { Number of active caps } \\
\text { and } 2010-2015 \\
\text { change in household } \\
\text { debt } \\
\text { Number of active caps } \\
\text { and } 2010-2019 \\
\text { change in household } \\
\text { debt }\end{array}$ & $\begin{array}{c}\mathbf{0 . 2 4} \\
(1.28 ; 0.2)\end{array}$ & $\begin{array}{l}28 \text { countries: AT, BE, BG, CY, CZ, DE, DK, } \\
\text { EE, ES, FI, FR, GR, HR, HU, IE, IT, LT, LU, } \\
\text { LV, MT, NL, PL, PT, RO, SE, SI, SK, UK }\end{array}$ \\
\hline $\begin{array}{l}\text { Number of active caps } \\
\text { and } 2015-2019 \\
\text { change in house prices }\end{array}$ & $\begin{array}{c}\mathbf{0 . 1 6} \\
(0.84 ; 0.4)\end{array}$ & $\begin{array}{l}29 \text { countries: AT, BE, BG, CY, CZ, DE, DK, } \\
\text { EE, ES, FI, FR, HR, HU, IE, IS, IT, LT, LU, } \\
\text { LV, MT, NL, NO, PL, PT, RO, SE, SI, SK, UK }\end{array}$ \\
\hline
\end{tabular}

Source: Authors using EViews 